\title{
PYRIMIDINE METABOLISM IN MAN. IV. THE ENZYMATIC DEFECT OF OROTIC ACIDURIA*
}

\author{
By LLOYD H. SMITH, Jk., MARGARET SULLIVAN ANI CHARLES M. \\ HUGULEY, JR. \\ (From the Department of Medicine, Massachusetts General Hospital, and Harvard Medical \\ School, Boston, Mass., and the Department of Medicine, Emory University, \\ School of Medicine, Atlanta, Ga.)
}

(Submitted for publication November 8, 1960; accepted December 12, 1960)

Orotic aciduria is a rare disorder which has thus far been described only in the propositus (1). This patient, a 9 month old child, exhibited retarded growth and development associated with megaloblastic anemia unresponsive to vitamin $B_{12}$, folic acid, ascorbic acid and iron. There was heavy crystalluria, demonstrated on subsequent study to be due to the excretion of large amounts of orotic acid, a pyrimidine nucleotide precursor absent from normal urine. Improvement of the anemia without reversal of the megaloblastic marrow followed treatment with glucocorticoid hormones. The administration of a mixture of pyrimidine nucleotides led to a complete hematological remission, a remarkable improvement in general well-being, and a prompt reduction in orotic acid excretion. The patient died of an overwhelming varicella infection in 1958. His surviving parents and three siblings were normal hematologically and exhibited no orotic acid in the urine on chromatographic examination.

These clinical studies indicated the presence of a metabolic block in the pathway of pyrimidine biosynthesis, with impaired conversion of orotic acid to uridine-5'-phosphate (Figure 1). This report describes the development of assays for orotidylic pyrophosphorylase and orotidylic decarboxylase, the sequential enzymes which catalyze this conversion. Reduced activities of both enzymes were found in circulating erythrocytes from the parents and two of the three siblings of the deceased propositus of orotic aciduria.

\section{EXPERIMENTAL PROCEDURE}

\section{Preparation of reactants}

Carboxyl-labeled orotic acid-C $\mathrm{C}^{\mathbf{1 4}}\left(\mathrm{OA}-\mathrm{C}^{14}\right)$ was purchased from New England Nuclear Corporation. Car-

\footnotetext{
* This study was supported by Research Grant A-1606 (C2) from the Institute of Arthritis and Metabolic Diseases, Bethesda, Md. A preliminary report of this work has been published in abstract form (The enzymatic defect of orotic aciduria. J. clin. Invest. 1960, 39, 1029).
}

boxyl-labeled orotidine-5'-phosphate- $\mathrm{C}^{14}\left(\mathrm{O} 5 \mathrm{P}-\mathrm{C}^{14}\right)$ was biosynthetically prepared essentially as described by Lieberman, Kornberg and Simms (2). Ammonium sulfate fractionation was used in the purification of orotidylic pyrophosphorylase from yeast (3). The yield was increased (to about 10 per cent) by the inclusion of azauridylic acid ${ }^{1}\left(6 \times 10^{-5} \mathrm{M}\right)$ in the incubation medium to inhibit any residual orotidylic decarboxylase (4). Uniformly labeled L-aspartate- $\mathrm{C}^{14}$ was purchased from Nuclear Chicago Corporation. $d l$-Dihydroorotate- $C^{14}$ was synthesized as previously described (5). 5-Phosphoribosylpyrophosphate (PRPP) was purchased as the magnesium salt from Sigma Chemical Corporation, converted to the sodium salt on a Dowex-50 ion exchange column, and assayed as described by Kornberg, Lieberman and Simms (6). Orotidylic decarboxylase was purified from baker's yeast by the method of Heppel and Hilmoe (7).

Erythrocytes were separated from approximately 25 $\mathrm{ml}$ of venous blood as previously described (5). The erythrocytes were frozen and maintained at $-10^{\circ} \mathrm{C}$ until assays for enzymatic activities were carried out on aliquots of the whole hemolysates. Pilot studies revealed no loss of enzymatic activity over a period of 1 week. Saliva obtained using paraffin stimulation was centrifuged at $25,000 \times G$ for 30 minutes, and the su. pernatant was assayed for enzymatic activity.

\section{Assay procedures}

The assay procedures, established after determining the characteristics of the enzyme systems in hemolysates of circulating erythrocytes, are modifications of those described by Lieberman and associates (2).

1. Orotidylic pyrophosphorylase. In this assay the release of carbon dioxide- $\mathrm{C}^{14}$ from carboxyl-labeled orotic acid- $\mathrm{C}^{14}$ was measured in the presence of optimal concentrations of $\mathrm{Mg}^{++}$and $\mathrm{PRPP}$ and of excess purified yeast orotidylic decarboxylase: OA-C $\mathrm{C}^{14}, 2.5 \times 10^{-4} \mathrm{M}(3.6$ $\times 10^{6} \mathrm{cpm}$ per $\mu$ mole); PRPP, $2.5 \times 10^{-4} \mathrm{M}$; $\mathrm{Mg}^{++}, 2.5$ $\times 10^{-3} \mathrm{M}$; yeast orotidylic decarboxylase, approximately

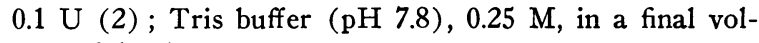
ume of $1 \mathrm{ml}$.

2. Orotidylic decarboxylase. Enzymatic activity was measured as the release of carbon dioxide- $\mathrm{C}^{\mathbf{1 4}}$ from biosynthetically prepared carboxyl-labeled oritidine-5'-phosphate: O5P-C ${ }^{14}, 5 \times 10^{-5} \mathrm{M}\left(3.6 \times 10^{6} \mathrm{cpm}\right.$ per $\mu$ mole $)$;

\footnotetext{
${ }^{1} \mathrm{We}$ are grateful to Dr. R. E. Handschumacher for a gift of azauridylic acid.
} 
phosphate buffer ( $\mathrm{pH} 6.6$ ) $0.25 \mathrm{M}$, in a final volume of $1 \mathrm{ml}$.

Incubations were carried out under air in the outer chamber of stoppered center-well $10-\mathrm{ml}$ Erlenmeyer flasks with constant shaking at $37^{\circ} \mathrm{C}$ for 60 minutes. The reactions were stopped by the introduction of excess sulfuric acid and shaking was continued for 45 minutes for completion of carbon dioxide trapping in center-well hyamine base (8). Radioactivity was measured using a Tricarb liquid scintillation spectrometer. ${ }^{2}$ Assays for aspartate carbamyltransferase and dihydroorotase and for isolation of orotic acid were carried out as previously described (5).

\section{Subjects}

Control studies were carried out on erythrocytes from laboratory personnel. Erythrocytes were obtained from the parents and the 3 surviving siblings (ages 16, 12 and 8 ) of the deceased patient with orotic aciduria. All of

2 Packard Instrument Company, La Grange, Ill.

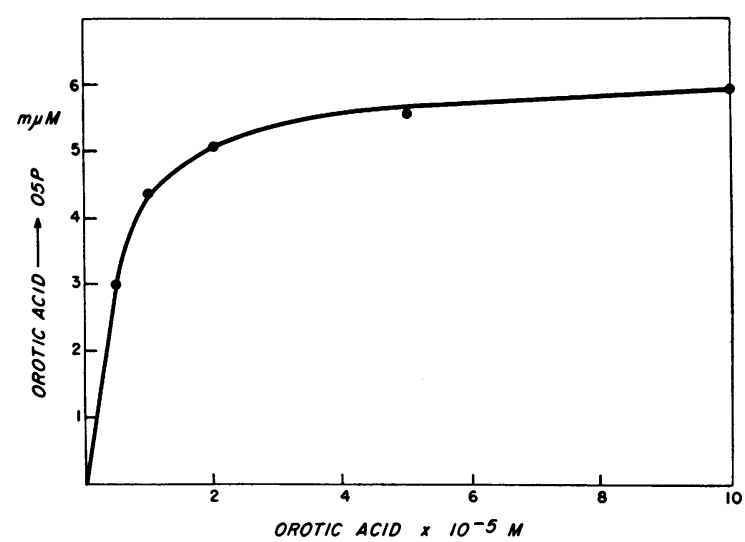

$\mathbf{A}$

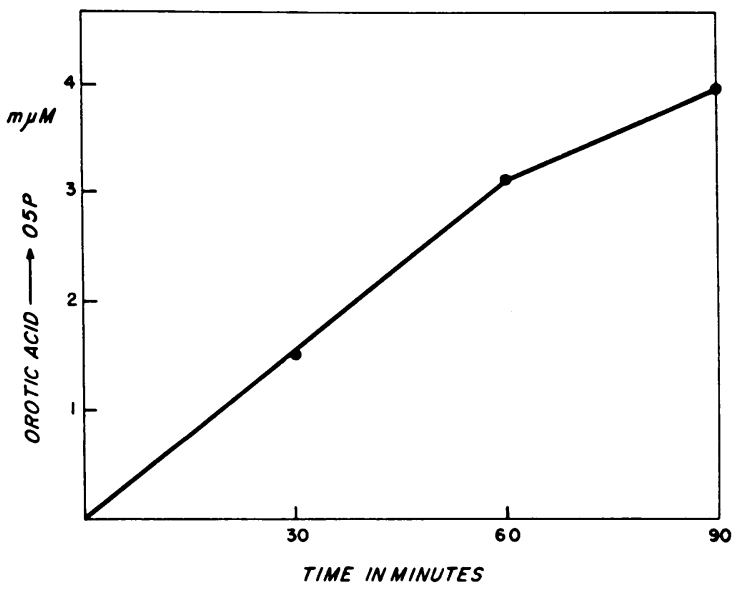

C

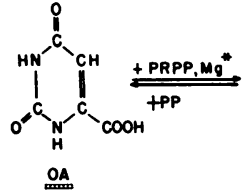

OROTIOYLIC PYROPHOSPHORYLASE
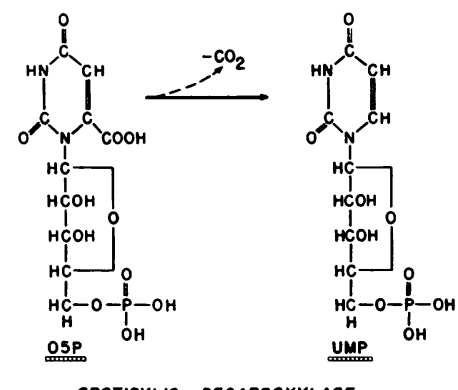

OROTIOYLIC DECARBOXYLASE

Fig. 1. The enzymatic CONVERSion OF OROTIC ACID to URIDINE-5'-PHOSPHATE. OA, orotic acid; PRPP, 5-phosphoribosylpyrophosphate; $\mathrm{PP}$, pyrophosphate; O5P, orotidine-5'-phosphate; UMP, uridine-5'-phosphate.

these subjects were normal hematologically and had exhibited normal growth and development. The parents and 2 brothers of another subject, presumably heterozygous for orotic aciduria, were also investigated. The
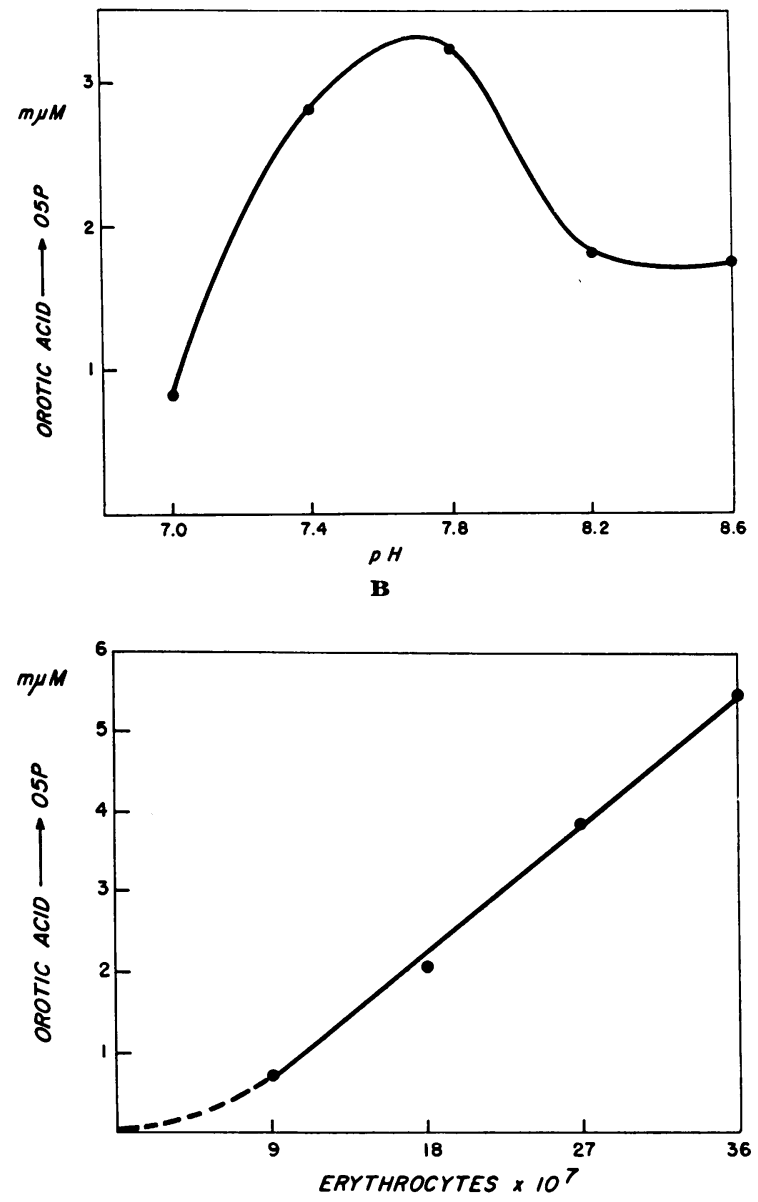

D

Fig. 2A) Substrate concentration curve of erythrocyte orotidylic pyrophosphorylase. B) PH curve of ERYTHROCYTE OROTIDYLIC PYROPHOSPHORYLASE. C) TIME CURVE OF ERYTHROCYTE OROTIDYLIC PYROPHOSPHORYLASE. D) ENZYME CONCENTRATION CURVE OF ERYTHROCYTE OROTIDYLIC PYROPHOSPHORYLASE. 


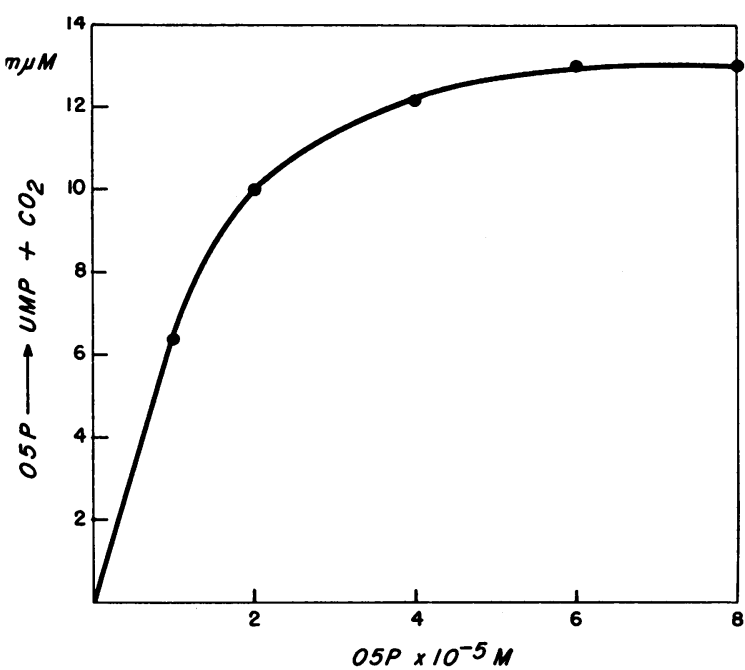

$\mathbf{A}$

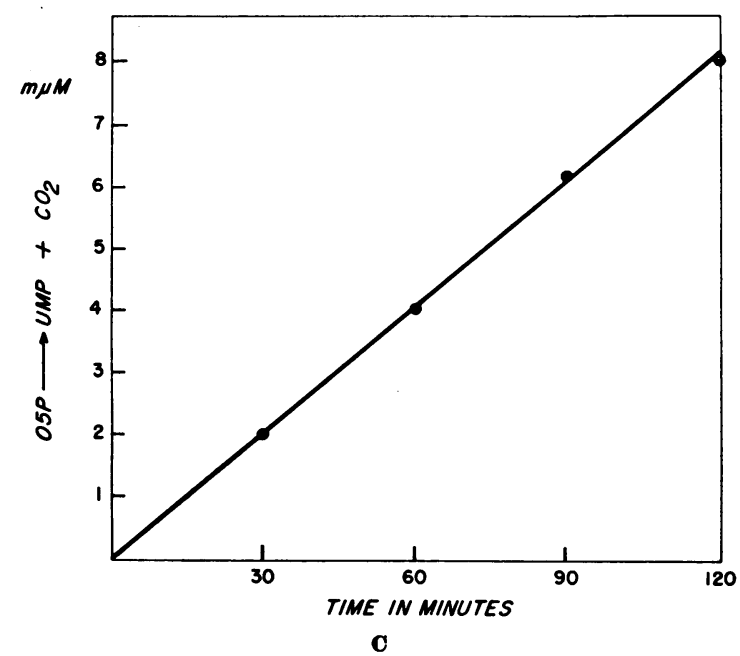

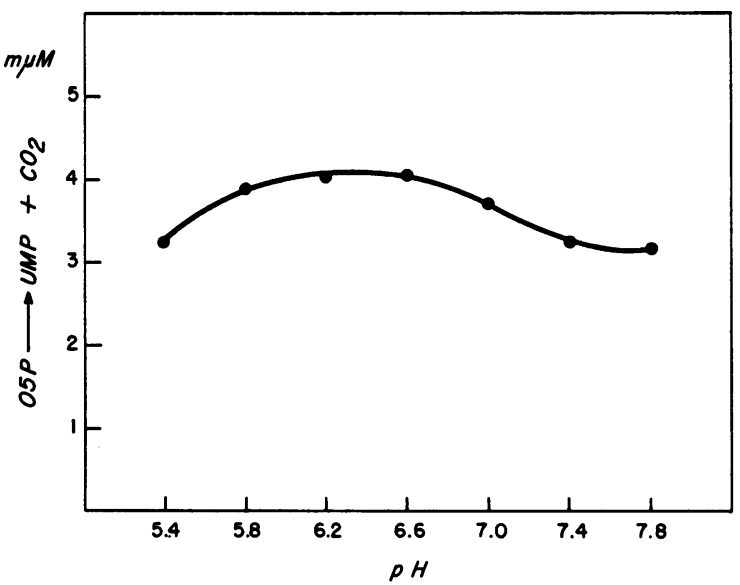

B

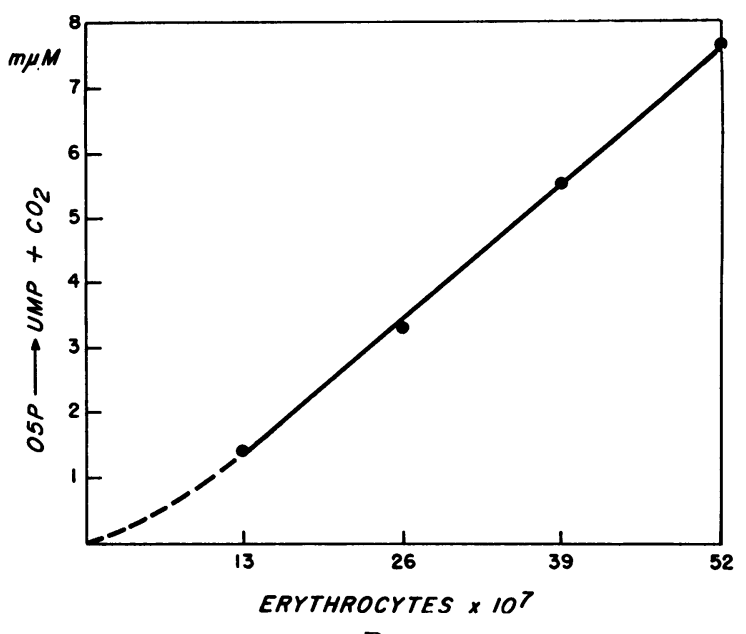

D

Fig. 3A) Substrate concentration curve of erythrocyte orotidylic decarboxylase. B) PH curve of ERyth-

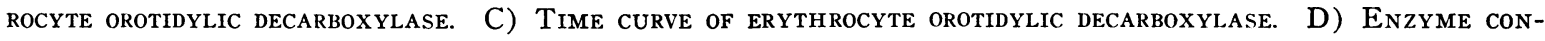
CENTRATION CURVE OF ERYTHROCYTE OROTIDYLIC DECARBOXYLASE.

father and 1 of the 2 brothers of the latter subject had hyperuricemia and clinical gout.

\section{RESULTS}

Orotidylic pyrophosphorylase. Orotidylic pyrophosphorylase, previously studied as a partially purified enzyme from yeast $(2,3)$, catalyzes the formation of orotidine- 5 -phosphate from orotic acid and 5-phosphoribosylpyrophosphate in the presence of $\mathrm{Mg}^{++}$(Figure 1). This reaction, a reversible pyrophosphorolysis, has also been studied less rigorously in experimental tumors (4) and in rat liver homogenates (9). Studies on the characteristics of this enzyme in human erythrocyte hemolysates are summarized by the series of graphs presented in Figure 2. The substrate concentration curve showed enzyme saturation to be attained at approximately $5 \times 10^{-5} \mathrm{M}$ orotic acid. The calculated $\mathrm{Km}$ for orotic acid in this system was $0.4 \times 10^{-5}$. Similarly the $\mathrm{Km}$ for PRPP was calculated to be $1.6 \times 10^{-5}$, although the instability of this compound and the wide variety of competing reactions in such a crude enzyme preparation detract from the significance of this value. In dialyzed preparations, $\mathrm{Mg}^{++}$was required with an optimal concentration of $2 \times 10^{-3} \mathrm{M}$. The $\mathrm{pH}$ 
activity curve demonstrated maximal synthesis of $\mathrm{O} 5 \mathrm{P}$ at 7.8. The reaction was linear with time over a period of 1 hour. It is to be noted that $05 \mathrm{P}$ synthesis was not proportional to enzyme concentration (number of hemolyzed erythrocytes) at rates of synthesis less than $1 \mathrm{~m} \mu$ mole per hour. This lack of a linear response at these extremely low rates of synthesis was also noted in studies of the orotidylic decarboxylase reaction on erythrocyte hemolysates (see below) and of dilute preparations of rat liver homogenates and partially purified yeast enzymes. The following manipulations failed to lead to a linear response in this section of the curve: use of an internal bicarbonate carrier; addition of glutathione, cysteine or human albumin; addition of a boiled extract of a hemolysate; incubation at $24^{\circ} \mathrm{C}$ or collecting $\mathrm{CO}_{2}$ at $56^{\circ} \mathrm{C}$. In all assay procedures, determinations were made on the linear part of the enzyme concentration curve. The reversibility of this reaction in erythrocyte preparations was demonstrated as the release of orotic acid- $\mathrm{C}^{14}$ from O5P$\mathrm{C}^{14}$ in the presence of inorganic pyrophosphate, but the characteristics of the backward reaction ( $\mathrm{pH}$ curve, time curve, substrate concentration curve) were not determined.

Orotidylic decarboxylase. Orotidylic decarboxylase catalyzes the irreversible decarboxylation of orotidine- 5 '-phosphate to uridine- 5 '-phosphate (2). This reaction has no known cofactors. Recent evidence suggests that the activity of the enzyme is influenced by the concentration of uridine$5^{\prime}$-phosphate (9), and is competitively inhibited by 6 -azauridylic acid (4). Some of the biochemical characteristics of orotidylic decarboxylase in human erythrocyte hemolysates are summarized in Figure 3. The substrate concentration curve indicated enzyme saturation at approximately $5 \times 10^{-5} \mathrm{M}$ O5P. The calculated $\mathrm{Km}$ for $\mathrm{O} 5 \mathrm{P}$ is $1.1 \times 10^{-5}$. There was a broad, flat $\mathrm{pH}$ curve with the optimal $\mathrm{pH}$ in the range 6.2 to 6.8 . The decarboxylation was linear with time over a period of 2 hours. The enzyme concentration curve deviated from a linear response at rates of carbon dioxide liberation of less than $1 \mathrm{~m} \mu$ mole per hour, as discussed concerning orotidylic pyrophosphorylase above. The reaction was not affected by ethylenediamine tetraacetic acid $\left(10^{-2}\right.$ $\mathrm{M})$, the addition of $\mathrm{Mg}^{++}$, or preincubation of the enzyme preparation with pyridoxalphosphate $(2 \times$ $\left.10^{-3} \mathrm{M}\right)$, biotin $\left(2 \times 10^{-3} \mathrm{M}\right)$, or avidin ( $1 \mathrm{U}$ per $\mathrm{ml})$.

Erythrocyte enzymatic activities in control subjects and in heterozygotes of orotic aciduria. The normal range of activity of orotidylic pyrophosphorylase per $10^{9}$ erythrocytes is summarized in Figure 4. Erythrocytes from the parents and two of the three siblings of the propositus of orotic aciduria (R. family) exhibited reductions of enzymatic activity while that of the third sibling was in the normal range. These determinations were carried out repeatedly and at varying enzyme concentrations. In the course of these studies, one subject (J.S.), chosen as an apparently normal control, was found to have consistently low levels of erythrocyte orotidylic pyrophosphorylase activity on five determinations over a period of several months. This subject was normal clinically and hematologically and was found to have a normal serum uric acid concentration. Studies of the parents and two brothers of J.S. (the S. family) revealed a tendency toward reduced activity of orotidylic pyrophosphorylase, but this was not statistically significant.

Orotidylic decarboxylase was also studied in the same subjects, and the enzyme activities per $10^{9}$ erythrocytes are summarized in Figure 5. A

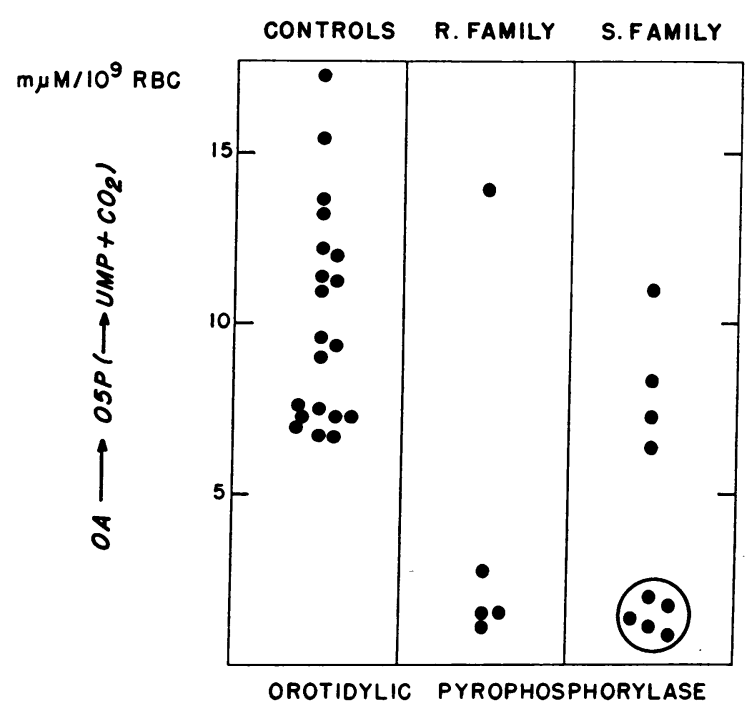

Fig. 4. OROTIDYLIC PYROPHOSPHORYLASE ACTIVITIES IN ERYTHROCYTES FROM CONTROL SUBJECTS AND PRESUMED HETEROZYGOTES OF OROTIC ACIDURIA. R. family: parents and 3 siblings of propositus of orotic aciduria. S. family: parents, siblings, and 5 determinations on a new heterozygote of orotic aciduria. 


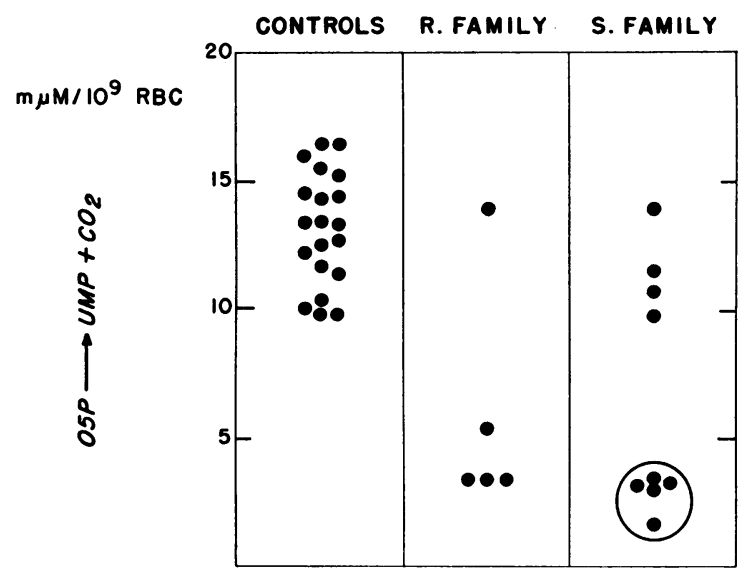

OROTIDYLIC DECARBOXYLASE

Fig. 5. Orotidylic DeCARboxylase activities in ERYTHROCYTES FROM CONTROL SUBJECTS AND PRESUMED HETEROZYGOTES OF OROTIC ACIDURIA.

pattern similar to that for orotidylic pyrophosphorylase was observed with a reduction of enzyme activity in the erythrocytes of four of the five surviving members of the R. family and in Subject J.S.

Since two consecutive enzymes in pyrimidine biosynthesis were found to be reduced in activity, it was imperative to demonstrate the specificity of these abnormalities. In Figure 6 are summarized studies of the enzymatic activities (per $10^{9}$ erythrocytes) of aspartate carbamyltransferase and dihydroorotase, enzymes prior to orotic acid biosynthesis. With the exception of one value that was unusually high, erythrocyte levels of these enzymes were normal in all subjects.

Mixtures of hemolysates from normal and "defective" erythrocytes were additive in enzymatic activities, evidence against the presence of an inhibitory agent. Within the limits imposed by nonpurified enzyme preparations, the Michaelis constants determined for orotic acid and orotidylic acid were the same for enzyme preparations from normal and "defective". erythrocytes.

Levels of enzymatic activities in saliva. Orotidylic pyrophosphorylase and orotidylic decarboxylase activities were also studied in saliva from a series of control subjects and from Subject J.S. As might be anticipated, there was a wide scatter of enzyme activity per milligram of $\mathrm{N}$ in the $25,000 \times G$ supernatant from saliva. Although the lowest activities of both enzymes were found in studies of J.S. (Figure 7), these values were not statistically significant due to the wide normal range.

\section{DISCUSSION}

In this study the metabolism of orotic acid in hemolysates of human erythrocytes was shown to follow the same pathway previously demonstrated in bacteria (2) and rat liver homogenates (9). Orotidylic pyrophosphorylase in man resembles the enzyme from $E$. coli in its optimal $\mathrm{pH}$ range, requirement for magnesium ions and 5-phosphoribosylpyrophosphate, and in its reversibility in the presence of inorganic pyrophosphate. The estimated $\mathrm{Km}$ for PRPP $\left(1.6 \times 10^{-5}\right)$ agrees closely with that previously reported $\left(2 \times 10^{-5}\right)$, but the $\mathrm{Km}$ for orotic acid $\left(0.4 \times 10^{-5}\right)$ was lower than that found for the partially purified bacterial enzyme $\left(2 \times 10^{-5}\right)$. Orotidylic decarboxylase exhibited a broad optimal $\mathrm{pH}$ range ( $\mathrm{pH} 6.2$ to 6.8). No cofactors could be demonstrated. Specifically the addition of pyridoxalphosphate or biotin and preincubation of the enzyme preparation with avidin did not alter enzyme activity. The $\mathrm{Km}$ for orotidine-5'-phosphate in human erythrocytes $\left(1.1 \times 10^{-5}\right)$ approximates that found with the bacterial enzyme $\left(1.4 \times 10^{-5}\right)$ (3). Low but reproducible activities of both enzymes were found in normal human erythrocytes.

Assay procedures have now been developed for five sequential enzymes in hemic cells leading to the formation of uridylic acid from simple precursors (Figure 8). Four of these enzymes-

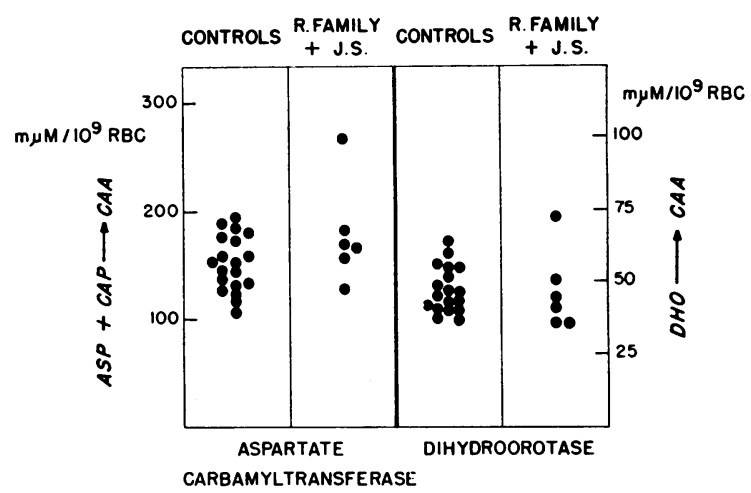

Fig. 6. Aspaktate Carbamyltransferase and DiHYDROOROTASE ACTIVITIES IN ERYTHROCYTES FROM CONTROL SUBJECTS AND PRESUMED HETEROZYGOTES OF OROTIC ACIDURIA. 


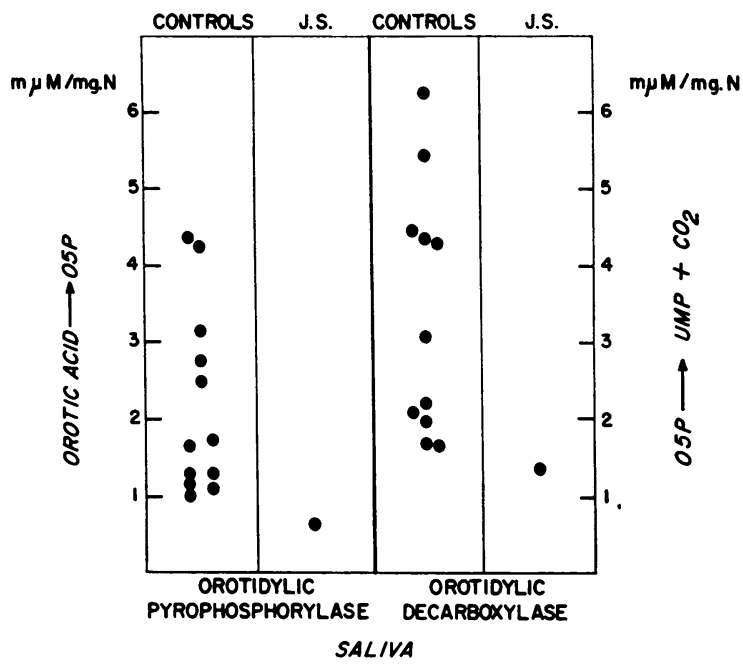

FIG. 7. LEVELS OF OROTIDYLIC PYROPHOSPHORYLASE AND OROTIDYLIC DECARBOXYLASE ACTIVITIES IN SALIVA FROM CONTROL SUBJECTS AND A SUBJECT (J.S.) PRESUMABLy HETEROZYGOUS FOR OROTIC ACIDURIA.

aspartate carbamyltransferase, dihydroorotase, orotidylic pyrophosphorylase and orotidylic decarboxylase-are present in reproducible activities in the mature human erythrocyte. Dihydroorotic dehydrogenase, which catalyzes the oxidation of dihydroorotic acid to orotic acid, is absent in the mature erythrocyte leading to a complete block in the de novo biosynthesis of pyrimidine nucleotides (Figure 8) (5). This erythrocyte enzyme pattern parallels that found in an $E$. coli mutant (ATCC no. 12632) which has a genetic block in dihydroorotic dehydrogenase activity (10). Erythrocytic dihydroorotic dehydrogenase seems to be lost during the process of maturation. Orotidylic pyrophosphorylase and orotidylic decarboxylase seem to be vestigial in the mature erythrocyte, which is unable to form precursor orotic acid, and is unique in containing no nucleic acids.

The propositus of orotic aciduria lied before this study was undertaken (1). No subsequent cases of this unusual syndrome have been described. Clinical investigation of the original patient seemed to establish quite clearly that there was a block in the conversion of orotic acid to uridine-5'-phosphate. 1) Large amounts of orotic acid $(0.5$ to $1.5 \mathrm{~g})$ were excreted in the patient's urine. This pyrimidine cannot be detected in normal urine. 2) There was a striking clinical and hematological remission during treatment with a mixture of pyrimidine nucleotides, substances distal to the presumed metabolic block. 3) Pyrimidine nucleotide treatment resulted in a reduction of orotic acid excretion, indicating a specificity of the therapeutic action. This finding is consistent with negative feedback control of pyrimidine biosynthesis, as demonstrated in E. coli in the classical studies of Yates and Pardee (11). The accumulation and excretion of orotic acid by the patient is analogous to the pattern of "pyrimidine starvation" seen in E. coli mutants grown in minimal media. A less marked pattern of pyrimidine starvation in man has been suggested from studies on pernicious anemia (12).

In the absence of blood cells or tissue from the deceased patient, studies were carried out on his surviving family members in an attempt to demonstrate a heterozygous defect. The data obtained demonstrated significant reductions of both orotidylic pyrophosphorylase and orotidylic decarboxylase activities in erythrocytes from the parents and two of the three siblings of the propositus. Both enzyme activities were normal in the

\section{MATURE ERYTHROCYTE}

NORMAL

OA'urio

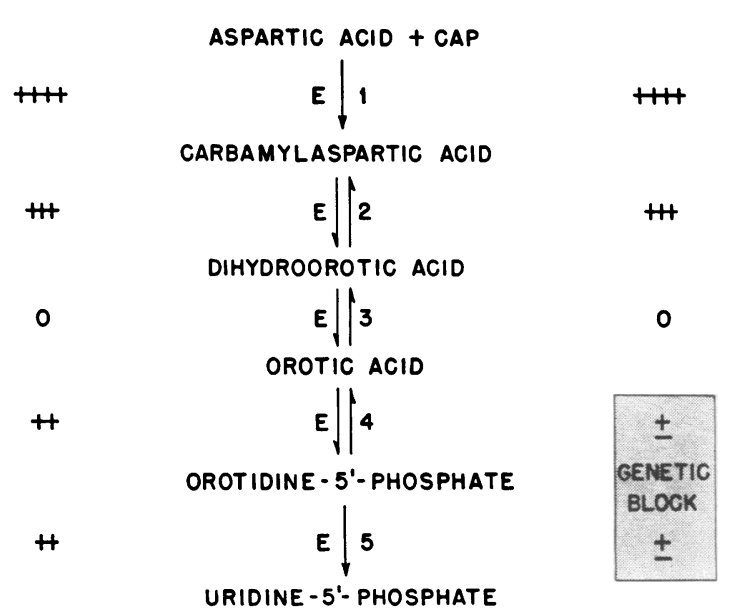

Fig. 8. Summary of LeVels of enzymes involved in URIDINE-5'-PHOSPHATE BIOSYNTHESIS IN NORMAL HUMAN ERYTHROCYTES AND IN ERYTHROCYTES OF SUBJECTS HETEROZYGOUS FOR OROTIC ACIDURIA. OA'uria, orotic aciduria; E1, aspartate carbamyltransferase; E2, dihydroorotase; E3, dihydroorotic dehydrogenase; E4, orotidylic pyrophosphorylase; E5, orotidylic decarboxylase. 


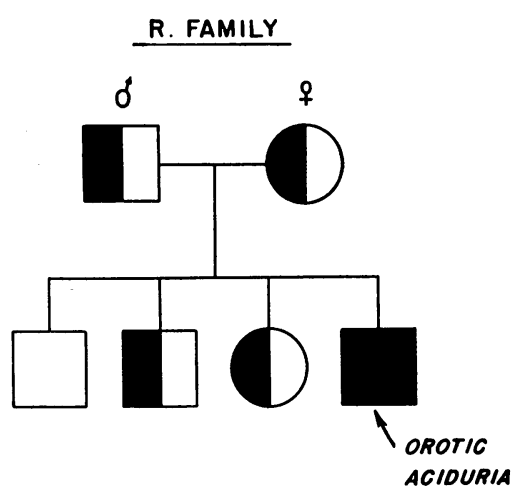

Fig. 9. Presumed pattern of inheritance of orotic ACIDURIA IN THE R. FAMILY.

third sibling. This pattern is consistent with the transmission of orotic aciduria as an autosomal recessive trait, with the deceased patient presumed to have been homozygous (Figure 9). There was no close consanguinity in the family, although the parents had a common ancestor who was the grandfather of the father and the greatgrandfather of the mother.

It is unlikely that the defect in the conversion of orotic acid to uridine- 5 '-phosphate was limited to the patient's erythropoietic system in view of his diversity of symptoms and failure of growth (1). Gastrointestinal symptoms were prominent, suggesting involvement of intestinal epithelium, a tissue which is known to undergo rapid regeneration. Preliminary observations suggest that reduced activities of orotidylic pyrophosphorylase and orotidylic decarboxylase are found in polymorphonuclear leukocytes from heterozygotes of orotic aciduria. In the syndrome of primaquinesensitive hemolytic anemia, deficiency of glucose6-phosphate dehydrogenase activity has been found in erythrocytes, platelets and leukocytes (13). Recent studies have shown the enzyme defect to be present also in saliva (14). Similarly, salivary levels of orotidylic pyrophosphorylase and orotidylic decarboxylase were found to be low in a heterozygote of orotic aciduria, although the wide range of normal values reduces the significance of this observation.

In previous studies of enzymatic abnormalities associated with human "inborn errors of metabolism," defects of single enzymes have been found, in keeping with the one gene-one enzyme hypothesis (15). Possible exceptions to this generaliza- tion have been reported as combined deficiencies of blood coagulation factors. Similarly, mutations in bacteria and Neurospora almost uniformly are specific for a single enzyme (16). In the current studies two sequential enzymes were found to be equally deficient. Specificity of these enzyme defects was indicated by finding normal erythrocyte levels of aspartate carbamyltransferase and dihydroorotase, earlier enzymes in the pyrimidine biosynthetic pathway. Studies of mixtures of hemolysates from normal and defective cells gave no evidence for the presence of an inhibitory agent. Further studies carried out in an attempt to determine whether the deficiency of one of these enzymes is more likely to be primary are reported elsewhere (17).

In the course of these studies another subject (J.S.) was found whose erythrocytes have repeatedly exhibited over a period of months reduced activities of orotidylic pyrophosphorylase and orotidylic decarboxylase with levels comparable to those found in the family of the patient with orotic aciduria. Preliminary observations suggest that the defect is also demonstrable in his leukocytes. The enzyme defects were "specific" in that normal erythrocyte levels of aspartate carbamyltransferase and dihydroorotase were found. It seems probable that this subject is also heterozygous for orotic aciduria. It is to be noted, however, that no clear-cut pattern of inheritance could be demonstrated in his immediate family. No large survey has as yet been undertaken to document the true incidence of the orotic aciduric defect. The finding of another presumed heterozygote in the current small series suggests that the abnormal gene may have wide distribution. If this is so, the rarity of the syndrome of orotic aciduria suggests that the genetic defect is usually lethal in the homozygous state. It may well be asked how the propositus of orotic aciduria was able to survive with a homozygous defect in the main pathway for the de novo synthesis of pyrimidine nucleotides. An analogous mutant in E. coli (ATCC no. 11548) exhibits the "orotic aciduria syndrome" in that it accumulates orotic acid in the medium and demonstrates a block in the conversion of orotic acid to uridine5 '-phosphate $(11,17)$. This organism fails to grow in the absence of an exogenous source of uracil or pyrimidine nucleotides. The patient 
failed to respond to the administration of large amounts of uracil, indicating an ineffective "salvage synthesis" of pyrimidine nucleotides from free pyrimidine bases, which are liberated in nucleic acid degradation (18). In the absence of an opportunity for direct measurements, it must be assumed that although homozygous, the patient was able to form orotidylic pyrophosphorylase and orotidylic decarboxylase in amounts sufficient for marginal survival. The phenomenon of interallele complementation in enzyme formation has recently been demonstrated in Neurospora crassa (19) and in some bacterial mutants. Here, the crossing of different mutants, each without detectable enzymatic activity, resulted in progeny with the ability to synthesize the enzyme in question. Enzyme production by interallele complementation has always resulted in levels of activity markedly reduced below those found in wild-type strains. It is possible that some such form of "genetic leakage" permitted the survival of the propositus of orotic aciduria.

The father and one brother of Subject J.R. have idiopathic hyperuricemia with typical attacks of gouty arthritis. The occurrence of a "pyrimidine disease" and of the most frequent "purine disease" in the same family is a provocative finding. The deceased patient with orotic aciduria exhibited no evident abnormality of uric acid metabolism. Subsequent studies of erythrocytes from ten subjects with idiopathic gout have failed to reveal the enzyme pattern of orotic aciduria (20). At the present time no definite relationship of orotic aciduria to gout has been established.

\section{SUM MARY}

1. Two enzymes which catalyze the conversion of orotic acid to uridine-5'-phosphate, orotidylic pyrophosphorylase and orotidylic decarboxylase, were found to be present in reproducible activities in circulating human erythrocytes. Both enzymes were also detected in saliva.

2. Reduced activities of orotidylic pyrophosphorylase and orotidylic decarboxylase were found in erythrocytes from the parent and two of the three siblings of the deceased propositus of orotic aciduria. The erythrocytes exhibited normal activities of aspartate carbamyltransferase and di- hydroorotase, earlier enzymes in the pyrimidine biosynthetic pathway.

3. The pattern of inheritance of orotic aciduria is consistent with that of an autosomal recessive trait.

4. In a small control series another heterozygote of orotic aciduria was discovered. It is suggested that the genetic disorder of orotic aciduria is usually lethal in its homozygous state.

\section{ACKNOWLEDGMENT}

The authors would like to express their appreciation to Dr. James A. Bain for his advice during the preparation of this manuscript.

\section{REFERENCES}

1. Huguley, C. M., Jr., Bain, J. A., Rivers, S. L., and Scoggins, R. B. Refractory megaloblastic anemia associated with excretion of orotic acid. Blood 1959, 14, 615.

2. Lieberman, I., Kornberg, A., and Simms, E. S. Enzymatic synthesis of pyrimidine nucleotides. Orotidine- $5^{\prime}$-phosphate and uridine- $5^{\prime}$-phosphate. J. biol. Chem. 1955, 215, 403.

3. Holmes, W. L. Studies on the mode of action of analogues of orotic acid: 6-Uracilsulfonic acid, 6-uracilsulfonamide, and 6-uracil methyl sulfone. J. biol. Chem. 1956, 223, 677.

4. Handschumacher, R. E. Orotidylic acid decarboxylase: Inhibition studies with azauridine 5'-phosphate. J. biol. Chem. 1960, 235, 2917.

5. Smith, L. H., Jr., and Baker, F. A. Pyrimidine metabolism in man. I. The biosynthesis of orotic acid. J. clin. Invest. 1959, 38, 798.

6. Kornberg, A., Lieberman, I., and Simms, E. S. Enzymatic synthesis and properties of 5-phosphoribosylpyrophosphate. J. biol. Chem. 1955, 215, 389.

7. Heppel, L. A., and Hilmoe, R. J. Purification and properties of 5-nucleotidase. J. biol. Chem. 1951, $188,665$.

8. Eisenberg, F., Jr. Round-table on "The preparation of the alkaline absorbent for radioactive $\mathrm{CO}_{2}$ in liquid scintillation counting" in Liquid Scintillation Counting, C. G. Bell, Jr. and F. N. Hayes, Eds. New York, Pergamon Press, 1958, p. 123.

9. Blair, D. G. R., Stone, J. E., and Potter, V. R. Formation of orotidine- 5 '-phosphate by enzymes from rat liver. J. biol. Chem. 1960, 235, 2379.

10. Yates, R. A., and Pardee, A. B. Pyrimidine biosynthesis in Escherichia coli. J. biol. Chem. 1956, 221, 743.

11. Yates, R. A., and Pardee, A. B. Control by uracil of formation of enzymes required for orotate synthesis. J. biol. Chem. 1957, 227, 677. 
12. Smith, L. H., Jr., and Baker, F. A. Pyrimidine metabolism in man. III. Studies on leukocytes and erythrocytes in pernicious anemia. J. clin. Invest. 1960, 39, 15.

13. Ramot, B., Fisher, S., Szeinberg, A., Adam, A., Sheba, C., and Gafni, D. A study of subjects with erythrocyte glucose-6-phosphate dehydrogenase deficiency. II. Investigation of leukocyte enzymes. J. clin. Invest. 1959, 38, 2234.

14. Ramot, B., Sheba, C., Adam, A., and Ashkenasi, I. Erythrocyte glucose-6-phosphate dehydrogenase-deficient subjects: Enzyme-level in saliva. Nature (Lond.) 1960, 185, 931.

15. Stanbury, J., Wyngaarden, J. B., and Fredericksen, D., Eds. Metabolic Basis of Inherited Diseases. New York, McGraw-Hill, 1960.
16. Fincham, J. R. S. Genetically controlled differences in enzyme activity. Advanc. Enzymol. 1960, $22,1$.

17. Smith, L. H., Jr., and Sullivan, M. Studies on the enzyme defect of orotic aciduria. Submitted for publication.

18. Reichard, P., and Sköld, O. Enzymes of uracil metabolism in the Ehrlich ascites tumour and mammalian liver. Biochim. biophys. Acta 1958, 28, 376.

19. Pateman, J. A., and Fincham, J. R. S. Gene-enzyme relationships at the am locus in Neurospora crassa. Heredity 1958, 12, 317.

20. Smith, L. H., Jr., and Sullivan, M. Unpublished observations. 